\title{
Mobile technologies in the Nursing area
}

\author{
Tecnologias móveis na área de Enfermagem \\ Tecnologías móviles en el área de Enfermería
}

\section{Alessandra Maria de Araújo Silva', Victor Hugo Alves Mascarenhas',Sarah Nilkece Mesquita Araújo', Raylane da Silva Machado', Ana Maria Ribeiro dos Santos', Elaine Maria Leite Rangel Andrade'

\author{
'Universidade Federal do Piauí, Department of Nursing. Teresina, Piauí, Brazil.
}

How to cite this article:

Silva AMA, Mascarenhas VHA, Araújo SNM, Machado RS, Santos AMR, Andrade EMLR. Mobile technologies in the nursing area. Rev Bras Enferm [Internet]. 2018;71(5):2570-8. DOI: http://dx.doi.org/10.1590/0034-7167-2017-0513

\author{
Submission: 07-21-2017_Approval: 11-18-2017
}

\section{ABSTRACT}

Objective: To identify in the literature studies on mobile technologies in Nursing. Method: Integrative literature review in which was used the Population, Interest and Context (PICo) strategy, the tool of the National Library of Medicine for formulation of the research question, and search without a determined period of time in the following bibliographic databases: Medical Literature and Retrieval System onLine/PubMed ${ }^{\circledR}$ ), Cumulative Index to Nursing \& Allied Health Literature (CINAHL), SCOPUS (Elsevier), Latin American and Caribbean Literature in Health Sciences (LILACS) and Nursing Database (BDENF). Data collection period was from January to March 2017. Results: Fifteen articles were selected, in which were addressed mobile technologies in Nursing for nurses, undergraduate students and patients. Conclusion: Mobile technologies in Nursing are a recent theme and enable care data sharing, experience acquisition by undergraduate students and patient empowerment.

Descriptors: Mobile Applications; Smartphone; Nursing Informatics; Application of Medical Informatics; Mobile Phones.

\section{RESUMO}

Objetivo: Identificar na literatura estudos sobre tecnologias móveis na área de enfermagem. Método: Revisão integrativa da literatura, utilizando a estratégia População, Interesse e Contexto (PICo), ferramenta da National Library of Medicine para formulação da questão de pesquisa e busca sem recorte temporal nas bases de dados bibliográficas: Medical Literature and Retrieval System onLine (MEDLINE/ PubMed ${ }^{\circ}$ ), Cumulative Index to Nursing \& Allied Health Literature (CINAHL), SCOPUS (Elsevier), Literatura Latino-Americana e do Caribe em Ciências da Saúde (LILACS) e Base de Dados em Enfermagem (BDENF). A coleta de dados ocorreu no período de janeiro a março de 2017. Resultados: Foram selecionados 15 artigos, que abordaram tecnologias móveis na área da enfermagem para enfermeiros, graduandos e pacientes. Conclusão: As tecnologias móveis na área da enfermagem são tema recente e possibilitam compartilhamento de dados na assistência, aquisição de experiência por graduandos e empoderamento do paciente.

Descritores: Aplicativos Móveis; Smartphone; Informática em Enfermagem; Aplicação de Informática Médica; Telefones Celulares.

\section{RESUMEN}

Objetivo: Identificar en la literatura estudios sobre tecnologías móviles en el área de Enfermería. Método: Revisión de la literatura en que se utilizó la estrategia Población, Interés y Contexto (PICo), herramienta de la National Library of Medicine para la formulación de la cuestión de la investigación y la búsqueda sin recorte temporal en las siguientes bases de datos bibliográficos: Medical Literature and Retrieval System onLine (MEDLINE/PubMed ${ }^{\circledR}$ ), Cumulative Index to Nursing \& Allied Health Literature (CINAHL), SCOPUS (Elsevier), Literatura Latinoamericana y del Caribe en Ciencias de la Salud (LILACS) y Base de Datos en Enfermería (BDENF). El período de la recolección de datos fue de enero a marzo de 2017. Resultados: Se seleccionaron 15 artículos, que abordaron tecnologías móviles en el área de Enfermería para enfermeros, estudiantes y pacientes. Conclusión: Las tecnologías móviles en el área de Enfermería son tema reciente y posibilitan compartir datos en la asistencia, adquisición de experiencia por estudiantes y empoderamiento del paciente.

Descriptores: Aplicaciones Móviles; Smartphone; Informática en Enfermería; Aplicación de Informática Médica; Teléfonos Móviles. 


\section{INTRODUCTION}

The term 'technology' has been misconceived as product, computerization, cybernetics and robotics. However, depending on the context, it can mean technical or scientific knowledge, tools, processes and materials created from such knowledge, which are related, base the Nursing care and generate solutions to practical problems ${ }^{(1)}$.

Information and Communication Technologies (ICTs) are all communication technologies that facilitate transmission of information through digital means, and include computers, wireless networks, among other devices. They have been used globally in personal, educational, business and health contexts ${ }^{(2)}$. In these contexts, from ICTs, it was also possible to process and transform data, images and voice, act on mechanisms that operate changes of state, sensors and actuators; to store, persist, maintain and recover data, images, voice and communication, and carry from one point to another what was processed and stored ${ }^{(3)}$.

Among ICTs, smartphones stand out because they enable communication, have several functionalities and offer many options for users given their efficient operating system and easy internet access ${ }^{(4)}$. In Brazil, according to the Global Mobile Consumer Survey, in 2016, $80 \%$ of people used smartphones daily, a very close percentage to the global average, which at that time was $81 \%{ }^{(5)}$.

Studies have been conducted in the health field for identifying the use of mobile technologies in the national and international literature. A systematic review of smartphone-based health technologies according to their functionality has shown that many smartphone applications are developed and used in health professionals' education, self-management of diseases and remote patient monitoring ${ }^{(6)}$. In Brazil, in another integrative review study, was identified that research involving mobile technologies applied to health has been more used for professional support ${ }^{(7)}$

The present study was proposed given the lack of an integrative review of the literature on mobile technologies in the Nursing area. Furthermore, it is part of a macro project with the aim to develop a smartphone application on intestinal elimination ostomy. Its result will allow the identification of the state of the art on mobile technologies in Nursing, of other gaps in the literature, and the expansion of the body of knowledge.

\section{OBJECTIVE}

To identify in the literature studies on mobile technologies in the Nursing area.

\section{METHOD}

An integrative literature review. It implies the analysis of relevant research that supports decision making and improvement of clinical practice, enables the synthesis of the knowledge state of a given subject, and points out knowledge gaps that need to be filled with new studies ${ }^{(8)}$.

The steps of this integrative review were the following: elaboration of the research question; sampling and data collection strategy; extraction of relevant data from primary studies; evaluation of studies; analysis and synthesis of the results of the review and presentation of the integrative review ${ }^{(9)}$.

The research question to be answered was 'What is the scientific production on mobile technologies in the Nursing area?'. It was developed by using the PICo strategy (Population/ Problem, Interest and Context), which is a tool of the National Library of Medicine. This strategy is based on segmentation of the research question, and allows researchers to select words that bring the appropriate definition of the initial questioning by identifying the best scientific information about the topic. Chart 1 describes the strategy used in the development of this review ${ }^{(10)}$.

Research question according to Population/Problem, Interest and Context (PICo) strategy, Brazil, 2016

\begin{tabular}{|c|c|c|c|c|c|}
\hline PICo & Components & Descriptor & Type & UND \\
\hline P & $\begin{array}{c}\text { Original } \\
\text { studies }\end{array}$ & - & - & - \\
\hline II & $\begin{array}{c}\text { Mobile } \\
\text { phone } \\
\text { applications }\end{array}$ & $\begin{array}{c}\text { "Computers, } \\
\text { handheld" }\end{array}$ & $\begin{array}{c}\text { "Smartphone" } \\
\text { "Mobile }\end{array}$ & $\begin{array}{c}\text { DeCS } \\
\text { MeSH } \\
\text { Emtree }\end{array}$ & $\begin{array}{c}\text { iPhoneAndroid } \\
\text { blackberry } \\
\text { blackberry } \\
\text { Windows } \\
\text { MobileWindows } \\
\text { Phone } \\
\text { deviceapplication }\end{array}$ \\
\hline CCo & Nursing & Nursing & $\begin{array}{c}\text { DeCS } \\
\text { MeSH }\end{array}$ & $\begin{array}{c}\text { nurs\$ } \\
\text { nurs* }\end{array}$ \\
\hline
\end{tabular}

Note: UND = Uncontrolled descriptor

The following bibliographic databases were used for the selection of articles: Medical Literature and Retrieval System onLine (MEDLINE/PubMed ${ }^{\circledR}$ ) via National Library of Medicine, Cumulative Index to Nursing\&Allied Health Literature (CINAHL); SCOPUS (Elsevier); Latin American and Caribbean Literature in Health Sciences (LILACS) and Nursing Database (BDENF). The controlled descriptors used in the search strategy were selected in MESH (Medical Subject Headings), DeCs (Health Sciences Descriptors) and Emtree (CINAHL Terminology), as well as uncontrolled descriptors (described in Chart 1). A search strategy was used for each bibliographic database (Chart 2).

Original articles in full and available online in selected bibliographic databases, published in Portuguese, English and Spanish (with no determined period of time) until the search was completed in December 2016 were included. Articles of theses, dissertations, review articles, non-material scientific papers, articles in which it was not possible to identify a relationship with the subject by reading title and abstract, and duplicate articles in the bibliographic databases were excluded.

The search and selection of articles were performed by two reviewers independently in order to give more rigor to this procedure. Initially, the selection of studies was performed by reading the titles 
Chart 2 - Search strategies according to bibliographic databases, Brazil, 2016

\begin{tabular}{|c|c|}
\hline Databases & Search strategy \\
\hline MEDLINE/PubMed ${ }^{\circledR}$ & 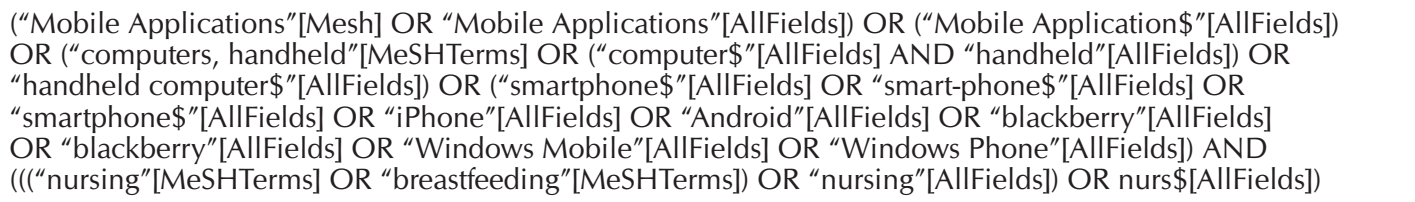 \\
\hline CINAHL & $\begin{array}{l}\text { ( (MH "Mobile Applications") OR "mobile application" ) OR ( ( (MH “Computers, Hand-Held") OR (MH "Comput- } \\
\text { ers, Portable") OR "computers, handheld" OR (MH "Smartphone") OR "smartphone" OR "iphone" OR "android" } \\
\text { OR "windowsphone" OR "windows mobile" OR "blackberry" OR "blackberrry") AND ( (nursing) OR (nurs*) ) ) } \\
\text { Limitadores - Revistas Acadêmicas } \\
\text { Restringir por Language: - portuguese } \\
\text { Restringir por Language: - spanish } \\
\text { Restringir por Language: - english } \\
\text { Modos de pesquisa - Booleano/Frase }\end{array}$ \\
\hline SCOPUS & 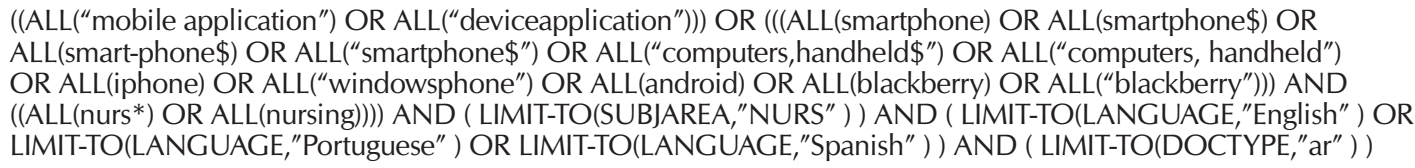 \\
\hline LILACS and BDENF & $\begin{array}{l}\text { (tw:("nursing")) OR (tw:(nurs*)) AND (tw:((tw:("Mobile Applications")) OR (mh:(“Mobile Applica- } \\
\text { tions")) OR (tw:(mobile application*)) OR (tw:("computers, handheld")) OR (tw:(handheld computer*)) } \\
\text { OR (tw:(smartphone)) OR (tw:(smartphone*)) OR (tw:(smart-phone*)) OR (tw:(smartphone*)) OR } \\
\text { (tw:(iphone) OR (tw:(android)) OR (tw:(blackberry)) OR (tw:("blackberry")) OR (tw:(“Windows Mobile")) OR } \\
\text { (tw:(windowsphone)))) AND (instance:"regional") AND ( db:(“LILACS" OR "BDENF")) }\end{array}$ \\
\hline
\end{tabular}

and abstracts based on inclusion criteria. From this selection, the remaining articles were read in full in order to include only relevant publications and consistent with the problem of the study.

After applying the inclusion and exclusion criteria, reading titles and abstracts, and full texts, the sample consisted of 15 articles. For the collection of information of articles, was used an instrument adapted from the literature $^{(11)}$ that included the following information: identification (authors, title, publication year and journal, database and mobile technologies in the Nursing area) and methodological characteristics (type of study/level of evidence).

Figure 1 shows a flowchart of the search and selection process of articles by bibliographic database.

In this review, the classification of the type of study/level of evidence was the following: level I: systematic review or meta-analysis of all relevant randomized controlled trials, or from clinical guidelines based on systematic reviews of randomized controlled trials; level II: at least one well-delineated randomized controlled clinical trial; level III: well-delineated clinical trials without randomization; level IV: well-delineated cohort and case-control studies; level V: systematic review of descriptive and qualitative studies; level VI: a single descriptive or qualitative study; level VII: opinion of authorities and/or report of expert committees ${ }^{(12)}$.

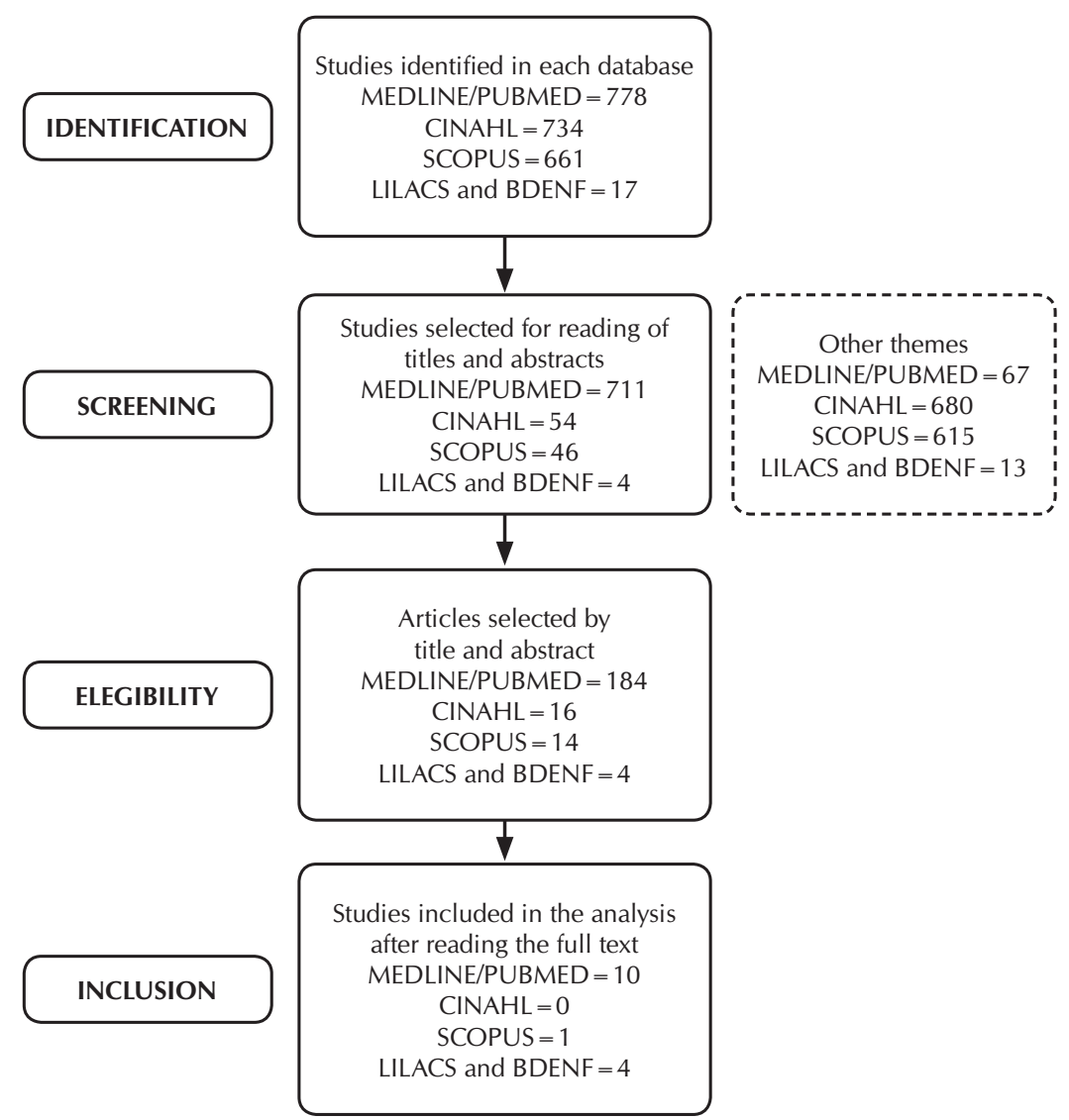

Figure 1 - Flowchart of the process of identification, screening, eligibility and inclusion of articles in the integrative literature review, Brazil, 2017 
The articles were analyzed descriptively and summarized in Charts with categorization of mobile technologies in Nursing according to the target audience: nurses, nursing undergraduate students and patients.

The research project of this review was not sent to the Research Ethics Committee (REC) because there is no direct involvement of human beings. In all stages of this review were respected the ethical principles and authors' copyright by citing each one of them.

\section{RESULTS}

Of the 218 articles selected by title and abstract, 203 mentioned the impact and usability of mobile technologies in the lives of patients and health professionals, but since there was no reference to the development process, these were not included in this study.
Of the 15 articles included, four were published in Brazil and 11 abroad. Regarding the target audience, six articles described mobile technologies in Nursing for nurses (Chart 3), two for undergraduate students and seven for patients (Chart 4).

Chart 3 and 4 show articles describing mobile technologies in Nursing for nurses, undergraduate students and patients according to authors, titles, year/journal, type of study/level of evidence and name of the application (when it was named and quoted by the author).

Almost all articles $(93 \%)^{(13-26)}$ are from the last five years. Seven $(46 \%)^{(13,16-17,20,22,24-25)}$ are from the two last years. In the majority $(87 \%)^{(13-22,24-25)}$, was used some qualitative method for evaluation of the mobile technology during its development, or the process and development stages were only described and classified as level $\mathrm{VI}^{(12)}$. In studies in which was used randomization $(13 \%)^{(13,24)}$, the aim was to compare participants' perceptions before and after the development and use of mobile technology.

Chart 3 - Articles selected for the study according to mobile technologies in Nursing for nurses, Brazil, 2017

\begin{tabular}{|c|c|c|c|c|c|}
\hline Database & Authors & Title & Year/Journal & $\begin{array}{l}\text { Type of study/ } \\
\text { Level of evidence }\end{array}$ & $\begin{array}{l}\text { Mobile technologies in } \\
\text { Nursing according to } \\
\text { target public }\end{array}$ \\
\hline $\begin{array}{l}\text { Study A } \\
\text { (LILACS and } \\
\text { BDENF) }\end{array}$ & $\begin{array}{l}\text { Velasco HF, Cabral } \\
\text { CZ, Pinheiro PP, } \\
\text { Azambuja RCS, Vitola } \\
\text { LS, Costa MR, et al. }\end{array}$ & $\begin{array}{l}\text { Use of digital media for } \\
\text { the education of health } \\
\text { professionals in the treatment } \\
\text { of childhood asthma }\end{array}$ & $\begin{array}{l}\text { 2015/ Jornal de } \\
\text { Pediatria }\end{array}$ & $\begin{array}{l}\text { Randomized } \\
\text { controlled trial/ } \\
\text { Level II }\end{array}$ & Not mentioned \\
\hline $\begin{array}{l}\text { Study B } \\
\text { (LILACS and } \\
\text { BDENF) }\end{array}$ & $\begin{array}{c}\text { Grossi, L.M.; Pisa, I.T.; } \\
\text { Marin, H.F. }\end{array}$ & $\begin{array}{c}\text { Oncoaudit: development and } \\
\text { evaluation of an application } \\
\text { for nurse auditors }\end{array}$ & $\begin{array}{l}\text { 2014/Acta } \\
\text { Paulista de } \\
\text { Enfermagem }\end{array}$ & $\begin{array}{l}\text { Qualitative and } \\
\text { quantitative study/ } \\
\text { Level VI }\end{array}$ & Oncoaudit \\
\hline $\begin{array}{l}\text { Study C } \\
\text { (LILACS and } \\
\text { BDENF) }\end{array}$ & $\begin{array}{l}\text { Catalan VM, Silveira } \\
\text { DT, Neutzling AL, } \\
\text { Martinato LHM, } \\
\text { Borges GCM. }\end{array}$ & $\begin{array}{c}\text { The NAS system: Nursing } \\
\text { Activities Score in mobile } \\
\text { technology }\end{array}$ & $\begin{array}{c}\text { 2011/Revista } \\
\text { da escola de } \\
\text { Enfermagem da } \\
\text { USP }\end{array}$ & $\begin{array}{c}\text { Descriptive study/ } \\
\text { Level VI }\end{array}$ & Nursing Activities Score \\
\hline $\begin{array}{l}\text { Study D } \\
\text { (Pubmed) }\end{array}$ & $\begin{array}{l}\text { Kim H, Chung } \\
\text { H,Wang S,Jiang } \\
\text { X,Choi J. }\end{array}$ & $\begin{array}{c}\text { SAPPIRE: a Prototype Mobile } \\
\text { Tool for Pressure Ulcer Risk } \\
\text { Assessment }\end{array}$ & $\begin{array}{l}\text { 2014/Studies } \\
\text { in Health } \\
\text { Technology } \\
\text { and Informatics }\end{array}$ & $\begin{array}{l}\text { Descriptive study/ } \\
\text { Level VI }\end{array}$ & $\begin{array}{l}\text { SAPPIRE(Skin } \\
\text { Assessment for Pressure } \\
\text { Ulcer Prevention, an } \\
\text { Integrated Recording } \\
\text { Environment) }\end{array}$ \\
\hline $\begin{array}{l}\text { Study E } \\
\text { (Pubmed) }\end{array}$ & $\begin{array}{c}\text { Wang J,Yao N,Wang } \\
\text { Y,Zhou F, Liu Y,Geng } \\
\text { Z,et al. }\end{array}$ & $\begin{array}{l}\text { Developing "Care Assistant": } \\
\text { A smartphone application to } \\
\text { support caregivers of children } \\
\text { with acutely lymphoblastic } \\
\text { leukemia }\end{array}$ & $\begin{array}{l}\text { 2015/ } \\
\text { Journal of } \\
\text { Telemedicine } \\
\text { and Telecare }\end{array}$ & $\begin{array}{c}\text { Descriptive study/ } \\
\text { Level VI }\end{array}$ & Care Assistant \\
\hline $\begin{array}{l}\text { Study F } \\
\text { (Pubmed) }\end{array}$ & $\begin{array}{l}\text { Warpenius E, } \\
\text { Alasaarela E,Sorvoja } \\
\text { H,Kinnunen M. }\end{array}$ & $\begin{array}{l}\text { A mobile user-interface } \\
\text { for elderly care from the } \\
\text { perspective of relatives }\end{array}$ & $\begin{array}{l}2015 / \\
\text { Informatics for } \\
\text { Health and } \\
\text { Social Care }\end{array}$ & $\begin{array}{l}\text { Descriptive study/ } \\
\text { Level VI }\end{array}$ & Not mentioned \\
\hline
\end{tabular}

Chart 4 - Articles selected for the study according to mobile technologies in Nursing for Nursing undergraduate students and patients, Brazil, 2017

\begin{tabular}{|c|c|c|c|c|c|}
\hline Database & Authors & Title & Year/Journals & $\begin{array}{c}\text { Type of study/ } \\
\text { Level of evidence }\end{array}$ & $\begin{array}{c}\text { Mobile technologies in } \\
\text { Nursing according to } \\
\text { target public }\end{array}$ \\
\hline $\begin{array}{c}\text { Study A } \\
\text { (LILACS } \\
\text { and } \\
\text { BDENF) }\end{array}$ & $\begin{array}{c}\text { Galvão, ECF, } \\
\text { Püschel, VAA. }\end{array}$ & $\begin{array}{c}\text { Multimedia application in } \\
\text { mobile platform for teaching the } \\
\text { measurement of central venous } \\
\text { pressure }\end{array}$ & $\begin{array}{c}2012 / \text { Revista } \\
\text { da escola de } \\
\text { Enfermagem da USP }\end{array}$ & $\begin{array}{c}\text { Qualitative study/ } \\
\text { Level VI }\end{array}$ & Not mentioned \\
\hline
\end{tabular}




\begin{tabular}{|c|c|c|c|c|c|}
\hline Database & Authors & Title & Year/Journals & $\begin{array}{l}\text { Type of study/ } \\
\text { Level of evidence }\end{array}$ & $\begin{array}{l}\text { Mobile technologies in } \\
\text { Nursing according to } \\
\text { target public }\end{array}$ \\
\hline $\begin{array}{l}\text { Study B } \\
\text { (Pubmed) }\end{array}$ & Juric,S.; Zalik, B & $\begin{array}{l}\text { An innovative approach tonear- } \\
\text { infrared spectroscopy using a } \\
\text { standard mobile device and its } \\
\text { clinical application in the real- } \\
\text { time visualization of peripheral } \\
\text { veins }\end{array}$ & $\begin{array}{c}\text { 2014/ BMC } \\
\text { medical } \\
\text { informatics and } \\
\text { decision making }\end{array}$ & $\begin{array}{c}\text { Qualitative study/ } \\
\text { Level VI }\end{array}$ & mVeinVision \\
\hline $\begin{array}{l}\text { Study C } \\
\text { (Pubmed) }\end{array}$ & $\begin{array}{l}\text { Chang CW, Ma } \\
\text { TY, Choi MS, } \\
\text { Hsu YY, Tsai YJ, } \\
\text { Hou TW }\end{array}$ & $\begin{array}{l}\text { Electronic personal maternity } \\
\text { records: Both web and } \\
\text { smartphone services }\end{array}$ & $\begin{array}{l}\text { 2015/ Computer } \\
\text { methods and } \\
\text { programs in } \\
\text { biomedicine }\end{array}$ & $\begin{array}{c}\text { Qualitative study/ } \\
\text { Level VI }\end{array}$ & Pregfone Care \\
\hline $\begin{array}{l}\text { Study D } \\
\text { (Pubmed) }\end{array}$ & $\begin{array}{c}\text { Jeon, E., Park, } \\
\text { HA. }\end{array}$ & $\begin{array}{l}\text { Development of a smartphone } \\
\text { Application for Clinical-Guideline } \\
\text { Based Obesity Management }\end{array}$ & $\begin{array}{l}\text { 2014/ Healthcare } \\
\text { Informatics } \\
\text { Research }\end{array}$ & $\begin{array}{c}\text { Qualitative study/ } \\
\text { Level VI }\end{array}$ & Not mentioned \\
\hline $\begin{array}{l}\text { Study E } \\
\text { (Pubmed) }\end{array}$ & $\begin{array}{c}\text { Kang H, Park } \\
\text { HA. }\end{array}$ & $\begin{array}{c}\text { Development of Hypertension } \\
\text { Management Mobile Application } \\
\text { based on Clinical Practice } \\
\text { Guidelines }\end{array}$ & $\begin{array}{l}\text { 2015/Studies in } \\
\text { Health Technology } \\
\text { and Informatics }\end{array}$ & $\begin{array}{c}\text { Descriptive study/ } \\
\text { Level VI }\end{array}$ & Not mentioned \\
\hline Study F & $\begin{array}{l}\text { Nes AAG, } \\
\text { Van Dulmen } \\
\text { S,Eide E,Finset } \\
\text { A,Kristjánsdóttir } \\
\text { OB,Steen IS,et } \\
\text { al. }\end{array}$ & $\begin{array}{l}\text { The development and feasibility } \\
\text { of a web-based intervention with } \\
\text { diaries and situational feedback } \\
\text { via smartphone to support self- } \\
\text { management in patients with } \\
\text { diabetes type } 2\end{array}$ & $\begin{array}{l}\text { 2012/ Diabetes } \\
\text { research and } \\
\text { clinical practice }\end{array}$ & $\begin{array}{c}\text { Descriptive study/ } \\
\text { Level VI }\end{array}$ & Not mentioned \\
\hline Study G & $\begin{array}{l}\text { Morrison CF, } \\
\text { Szulczewski } \\
\text { L,Strahlendorf } \\
\text { LF,Lane } \\
\text { JB,Mullins } \\
\text { LL,Pai AL }\end{array}$ & $\begin{array}{l}\text { Designing Technology to Address } \\
\text { Parent Uncertainty in } \\
\text { Childhood Cancer }\end{array}$ & $\begin{array}{l}\text { 2016/ Advances in } \\
\text { Nursing Science }\end{array}$ & $\begin{array}{l}\text { Randomized } \\
\text { controlled trial/ } \\
\text { Level II }\end{array}$ & Not mentioned \\
\hline Study H & $\begin{array}{l}\text { Jaensson M, } \\
\text { Dahlberg K, } \\
\text { Eriksson M, } \\
\text { Grönlund A, } \\
\text { Nilsson U. }\end{array}$ & $\begin{array}{l}\text { The Development of the Recovery } \\
\text { Assessments by Phone Points } \\
\text { (RAPP): A Mobile Phone App } \\
\text { for Postoperative Recovery } \\
\text { Monitoring and Assessment }\end{array}$ & $\begin{array}{l}\text { 2015/ JMIR } \\
\text { mHealth and } \\
\text { uHealth }\end{array}$ & $\begin{array}{c}\text { Descriptive study/ } \\
\text { Level VI }\end{array}$ & $\begin{array}{l}\text { Recovery Assessments } \\
\text { by Phone Points } \\
\text { (RAPP) }\end{array}$ \\
\hline Study I & $\begin{array}{c}\text { Cho MJ, Sim JL, } \\
\text { Hwang SY. }\end{array}$ & $\begin{array}{l}\text { Development of Smartphone } \\
\text { Educational Application for Patients } \\
\text { with Coronary Artery Disease }\end{array}$ & $\begin{array}{l}\text { 2014/Healthcare } \\
\text { Informatic } \\
\text { Research }\end{array}$ & $\begin{array}{c}\text { Descriptive study/ } \\
\text { Level VI }\end{array}$ & Strong Heart \\
\hline
\end{tabular}

\section{DISCUSSION}

The use of ICTs in Nursing has changed the way of dealing with massive amounts of information on care and resources used in a fast and organized way. Mobile technologies are a way of storing and sharing information, they improve the Nursing team performance and promote customer care ${ }^{(27)}$.

Smartphone mobile technologies enable a range of computing activities and telephony activities such as data access, internet browsing, e-mail sending and receiving, instant messaging applications, wireless communication technology ( $\left.\mathrm{Wi}-\mathrm{Fi}^{\circledR}\right)$, among others. In the health and nursing context, several functions can be used by patients or professionals. Emerging mobile technologies allow that professionals share information in real time, obtain data through a wireless system, and stimulate the self-care of patients of certain clinical conditions ${ }^{(28)}$.

These technologies fit into the context of mHealth, which means "health and medical practice supported by mobile devices such as mobile phones, patient monitoring devices, Personal Digital Assistants (PDAs) and other wireless devices"(29). This modality of patient care has been growing in line with the innovation of mobile devices, their popularization and new demands on patient health care $^{(30)}$.

\section{Mobile technologies in Nursing for nurses}

Mobile technologies have proven innovative in Nursing practice and changed the way nurses perform their interventions and communicate with patients and other health professionals. This allows for preventive and diagnostic actions, and for disease treatment ${ }^{(31)}$.

In general, nurses are open to the acquisition of mobile technologies at work for reducing the time in insertion and sharing of patient data. Mobile technologies should not be an extra form of record, but rather facilitators of systematization and access to patient information and the care process ${ }^{(32)}$.

Mobile technologies are tools for expanding the knowledge and systematization of work, and offer nurses the opportunity to 
strengthen ties with patients and family members, and provide guidance regarding self-care. Patient engagement in health care places nurses in the role of consultants and advisors and improves outcomes, especially in the management of chronic diseases. To this end, Nursing professionals need to be able to handle mobile technologies, know their potentialities and limitations ${ }^{(33)}$.

In this study, the mobile technologies in Nursing for nurses mentioned in Chart 3 presented several purposes, namely: educational tool for acquiring practical knowledge in the treatment of asthma ${ }^{(13)}$, management tool in auditing hospital bills ${ }^{(14)}$, access and sharing of data in a hospital system through a smartphone ${ }^{(34)}$, coding system for pressure ulcer risk assessment items ${ }^{(15)}$, support system for caregivers of children with acute lymphoblastic leukemia ${ }^{(16)}$ and elderly care ${ }^{(17)}$.

Despite the different purposes mentioned in studies in Chart 3 , all publications converge to the need for usability and user satisfaction. Seeking to improve functionality and attractiveness, software development professionals and health researchers use evaluative tools. In study B (described in Chart 3) ${ }^{(14)}$, professionals specialized in the creation of the mobile technology in question used the heuristic evaluation of Nielsen. This evaluation is performed through principles (heuristics) observed by more than one evaluator, who has the role of finding problems and suggesting usability improvements ${ }^{(35)}$. The evaluation performed by health researchers is usually done through satisfaction questionnaires or interviews with participants in a subjective way.

Mobile technologies in Nursing for undergraduate students Considering the change caused by ICTs in Nursing practice, the training process of future professionals must follow this evolution and present new strategies for knowledge acquisition. The availability of technological means throughout undergraduate studies prepares students for the field, since nowadays, work places are incorporating mobile technologies, shortening time, work and optimizing assistance ${ }^{(36)}$.

The use of mobile technologies as field simulation tools is done in an experience report on the use of an iPad application during patient care simulation. The application provided several pertinent auscultation sounds to the clinical case in question. This allowed that students had a practice experience similar to reality, and the opportunity to improve their skills, thereby generating less exposure and risk to the patient because of students' inexperience $^{(37)}$. In the same perspective, in study B (described in Chart 4), was demonstrated how the mVeinVision application helped Nursing students to improve their venipuncture technique by causing less harm to the patient ${ }^{(19)}$.

In the present study, only two articles addressed mobile technologies in Nursing for undergraduate students. This demonstrates that even though this resource expedites problem solving and develops communication and management skills, and information access, the use of technologies by educational institutions and teachers has limitations. There are several negative points, such as unavailability of technological resources to all students, failure during the use of device, lack of teachers' knowledge regarding use of device, and focus on individual work rather than teamwork ${ }^{(38-39)}$.

\section{Mobile technologies in Nursing for patients}

Population aging and increasing rates of chronic or disabling diseases require resources that reduce morbidity and mortality and allow self-management of the disease by patients and family members. In this context, mobile technologies are a useful alternative and of easy access to patients, since these tools are part of the daily lives of a large part of the world population. In the Nursing setting, they are allies in the control of disease symptomatology, drug adherence and nurse-patient communication ${ }^{(40)}$.

In the findings of this review related to mobile technologies in Nursing for patients, there were studies with target audiences with different diseases/health conditions, such as pregnant women, obese, hypertensive, diabetic, children with cancer, people in the postoperative period and patients with heart disease. In general, the aim of mobile technologies in these studies was the digital reproduction of information, guidelines and monitoring of health conditions routinely performed personally in consultations.

Limitations on the use of these mobile technologies included the following: lack of ability to use the mobile phone tool, small font size due to cell phone or tablet screen, difficult internet access and fear of dehumanization in care. Recommendations for improvement include: improving interactivity between the patient and mobile technology, providing simple information, detailing functions, reproducing information from clinical practice protocols, and creating decision support systems based on user response.

The aim of mobile technologies in Nursing is not the replacement of nurse-patient personal contact, but rather to act complementarily to consultations by providing patients' empowerment about their health condition and enabling their awareness on their role in their quality of life. In addition, daily care enabled by mHealth reduces the occurrence of crisis in chronic patients because information on changes in their health status can be evaluated in real time, which avoids unnecessary displacement and time spent in health units ${ }^{(41)}$.

\section{Limitations of the study}

In this review, publications with higher levels of evidence were scarce, which is explained by the descriptive design of most studies. The strategies used in the development and evaluation of mobile technologies were varied, highlighting the subjectivity of evaluation by research nurses, and scarce use of standardized scales of evaluation. The convenience sample was the most used by researchers, which generated results that cannot be applied to any type of population.

\section{Contributions for Nursing}

Knowing the reality about mobile technologies in Nursing made it possible to synthesize what is in the literature, identify unmet needs, and foster new research with fewer gaps in design and performance. Consequently, evidence can be better through studies with elaborated methods.

\section{CONCLUSION}

The articles selected in this review were on mobile technologies in Nursing for nurses, undergraduate students and patients. The profile of selected articles indicates the theme 
is recent and developed in countries where there are more technological resources.

For professionals, the possibilities of creating mobile technology range from the record of patient data, mean of information about diseases, managerial and administrative activities, among others. The increasing complexity of patients' cases and of nurses' job demands encourages the development of mobile technologies that make the work agile and optimize professionals' time during care and management activities.

Despite these limitations, mobile technologies can be great allies for building students' knowledge and their acquisition of experience before entering fields of practice.

For the technology business, patients represent a growing consumer market of mobile technology, which is no different when it comes to health. In this study, the aim of mobile technologies in Nursing for patients is empowering their health, self-care and frequent monitoring of changes in their health conditions by complementing nursing consultations.

In summary, results indicate the need for new studies on mobile technologies in Nursing, especially with undergraduate students. New studies may fill the current gaps and contribute to the practice of flexible, systematized and safe Nursing.

\section{ACKNOWLEDGEMENT}

We thank Professor Cristiane Borges de Moura Rabelo (Masters' degree in Nursing) for the contributions that allowed the enrichment of this work.

\section{REFERENCES}

1. Nietsche EA, Teixeira E, Medeiros HP. Tecnologias cuidativo-educacionais: uma possibilidade para empoderamento do(a) enfermeiro(a)? Porto Alegre: Moriá; 2014. 213p.

2. Zuppo CM. Defining ICT in a boundaryless world: the development of a working hierarchy. IJMIT [Internet]. 2012 [cited 2017 May 31];4(3). Available from: https://pdfs.semanticscholar.org/9c00/ff69df8dc109faccdba154f2768d93193f14.pdf.

3. Schmeil MA. Saúde e Tecnologia da Informação e Comunicação. Fisioter Mov[Internet]. 2013[cited 2017 Sep 30];26(3):477-8. Available from: http://www.scielo.br/pdf/fm/v26n3/a01v26n3.pdf

4. Pitichat T. Smartphones in the workplace: changing organizational behavior, transforming the future. LUX [Internet]. 2013[cited 2017 May 31];3(1). Available from: http://scholarship.claremont.edu/cgi/viewcontent.cgi?article =1038\&context =lux

5. Deloitte Touche Tohmatsu Limited. Mobile Consumer Survey 2016: hábitos dos usuários e tendências para o mercado de telecomunicações[Internet]. 2016[cited 2017 Jun 06]. Available from: https://www2.deloitte.com/br/pt/pages/technology-mediaand-telecommunications/articles/mobile-survey.html.

6. Mosa ASM, Yoo I, Sheets L. A systematic review of healthcare applications for smartphones. BMC Med Inform Decis Mak[Internet]. 2012[cited 2017 May 31];12:67. Available from: https://bmcmedinformdecismak.biomedcentral.com/track/ pdf/10.1186/1472-6947-12-67? site = bmcmedinformdecismak.biomedcentral.com.

7. Tibes CMS, Dias JD, Zem-Mascarenhas SH. Aplicativos móveis desenvolvidos para a área da saúde no Brasil: revisão integrativa da literatura. Rev Mineira Enferm[Internet]. 2014[cited 2017 May 31];18(2):471-8.Available from: http://www.reme.org.br/artigo/ detalhes $/ 940$

8. Polit DF, Beck CT. Using research in evidence-based nursing practice. In: Polit DF, Beck CT, (Eds.). Essentials of nursing research. Methods, appraisal and utilization. Philadelphia, USA: Lippincott Williams \& Wilkins; 2006. p.457-94.

9. Galvão CM, Mendes KDS, Silveira, RCCP. Revisão integrativa: método de revisão para sintetizar as evidências disponíveis na literatura. In: Brevidelli MM, Sertório SCM. TCC - Trabalho de conclusão de curso: guia prático para docentes e alunos da área da saúde. $4^{\mathrm{a}}$ ed. São Paulo: látria, 2010, p. 105-126.

10. Karino ME, Felli VEA. Enfermagem Baseada em Evidências: avanços e inovações em revisões sistemáticas. Ciênc Cuid Saúde[Internet]. 2012 [cited 2017 Sep 25];11:11-5. Available from: http://periodicos.uem.br/ojs/index.php/CiencCuidSaude/article/view/17048/pdf

11. Ursi ES. Prevenção de lesões de pele no perioperatório: revisão integrativa da literatura [Dissertação]. Escola de Enfermagem de Ribeirão Preto, Universidade de São Paulo, Ribeirão Preto, 2005.

12. Melnyk BM, Fineout-overholt E. Evidence-based practice in nursing and health care: a guide to best practice. Philadelphia: Lippincott, Williams \& Wilkins; 2011

13. Velasco HF, Cabral CZ, Pinheiro PP, Azambuja RCS, Vitola LS, Costa MR, et al. Use of digital media for the education of health professionals in the treatment of childhood asthma. J Pediatr[Internet]. 2015 [cited 2017 May 31];91(2):183-8. Available from: http://www.scielo.br/pdf/jped/v91n2/0021-7557-jped-91-02-00183.pdf

14. Grossi LM, Pisa IT, Marin HF. Oncoaudit: development and evaluation of an application for nurse auditors. Acta Paul Enferm[Internet]. 2014[cited 2017 May 31];27(2):179-85. Available from: http://www.scielo.br/pdf/ape/v27n2/en_0103-2100-ape-27-02-0179.pdf

15. Kim H, Chung H, Wang S, Jiang X, Choi J. SAPPIRE: a prototype mobile tool for pressure ulcer risk assessment. Stud Health Technol Inform [Internet]. 2014[cited 2017 May 31];201:433-40. Available from: https://www.ncbi.nlm.nih.gov/pmc/articles/PMC4414243/ pdf/nihms656463.pdf

16. Wang J, Yao N, Wang Y, Zhou F, Liu Y, Geng Z, et al. Developing "Care Assistant": a smartphone application to support caregivers 
of children with acute lymphoblastic leukaemia. J Telemed Telecare[Internet]. 2016[cited 2017 May 31];22(3):163-71. Available from: https://www.ncbi.nlm.nih.gov/m/pubmed/26271029/

17. Warpenius E, Alasaarela E, Sorvoja H, Kinnunen M. A mobile user-interface for elderly care from the perspective of relatives. Inform Health Soc Care[Internet]. 2015 [cited 2017 May 31];40(2):113-24. Available from: http://www.tandfonline.com/doi/abs/ 10.3109/17538157.2013.879148?journalCode =imif20

18. Galvão ECF, Püschel VAA. Multimedia application in mobile platform for teaching the measurement of central venous pressure. Rev Esc Enferm USP[Internet]. 2012[cited 2017 May 31];46(Spe):107-15. Available from: http://www.scielo.br/pdf/reeusp/v46nspe/ en_16.pdf

19. Juric S, Zalik B. An innovative approach tonear-infrared spectroscopy using a standard mobile device and its clinical application in the real-time visualization of peripheral veins. BMC Med Inform Decis Mak[Internet]. 2014 [cited 2017 May 31] 14:100. Available from: https://www.ncbi.nlm.nih.gov/pmc/articles/PMC4251692/

20. Chang CW, Ma TY, Choi MS, Hsu YY, Tsai YJ, Hou TW. Electronic personal maternity records: both web and smartphone services. Comput Methods Programs Biomed[Internet]. 2015 [cited 2017 May 31];121(1):49-58. Available from: https://europepmc.org/ abstract/med/26004998

21. Jeon E, Park HA. Development of a smartphone application for clinical-guideline-based obesity management. Healthc Inform Res[Internet]. 2015[cited 2017 May 31];21(1):10-20. Available from: https://www.ncbi.nlm.nih.gov/pmc/articles/PMC4330194/ pdf/hir-21-10.pdf

22. Kang H, Park HA. Development of hypertension management mobile application based on clinical practice guidelines. Stud Health Technol Inform[Internet]. 2015[cited 2017 May 31];210:602-6. Available from: http://ebooks.iospress.nl/publication/39413

23. Nes AAG, van Dulmen S, Eide E, Finset A, Kristjánsdóttir OB, Steen IS, et al. The development and feasibility of a web-based intervention with diaries and situational feedback via smartphone to support self-management in patients with diabetes type 2. Diabetes Res Clin Pract [Internet]. 2012[cited 2017 May 31];97(3):385-93. Available from: https://www.ncbi.nlm.nih.gov/ pubmed/22578890

24. Morrison CF, Szulczewski L, Strahlendorf LF, Lane JB, Mullins LL, Pai AL. Designing technology to address parent uncertainty in childhood cancer. Adv Nurs Sci[Internet]. 2016[cited 2017 May 31];39(1):15-25. Available from: https://www.ncbi.nlm.nih.gov/ pubmed/26836990

25. Jaensson M, Dahlberg K, Eriksson M, Grönlund $\AA$, Nilsson U. The development of the recovery assessments by phone points (RAPP): a mobile phone app for postoperative recovery monitoring and assessment. JMIRM[Internet]. 2015[cited 2017 May 31];3(3). Available from: https://www.ncbi.nlm.nih.gov/pmc/articles/PMC4704964/

26. Cho MJ, Sim JL, Hwang SY. Development of smartphone educational application for patients with coronary artery disease. Healthc Inform Res[Internet]. 2014[cited 2017 May 31];20(2):117-24. Available from: https://www.ncbi.nlm.nih.gov/pmc/articles/ PMC4030055/pdf/hir-20-117.pdf

27. Marin HF, Cunha ICKO. Perspectivas atuais da Informática em Enfermagem. Rev Bras Enferm [Internet]. 2006[cited 2017 Sep 25];59(3):354-7. Available from: http://www.scielo.br/pdf/reben/v59n3/a19v59n3.pdf

28. Bajwa M. Emerging 21st Century Medical Technologies. Pak J Med Sci [Internet]. 2014[cited 2017 May 31];30(3):649-55. Available from: https://www.ncbi.nlm.nih.gov/pmc/articles/PMC4048524/pdf/pjms-30-649.pdf

29. OMS. Health: new horizons for health through mobile technologies. 2011[cited 2017 May 31]. Available from: http.//www.who. int/goe/publications/gpe_mhealth_web.pdf

30. Sociedade Brasileira de Patologia Clínica/Medicina Laboratorial. Tecnologia da Informação em Medicina Laboratorial Posicionamento da SBPC/ML 2015: Interoperabilidade de sistemas. Edição 2015.

31. Doswell WM, Braxter B, DeVito Dabbs A, Nilsen W, Klem ML. mHealth: Technology for nursing practice, education, and research. J Nurs Educ Pract[Internet]. 2013[cited 2017 May 31]; 3(10).Available from: http://www.sciedu.ca/journal/index.php/jnep/article/ view/2180/1495

32. Ostrovsky Y, Buttaro TM, Diamond J, Hayes J. Technology and dynamic pathways: how to improve nursing care, documentation, and efficiency. Iproc[Internet]. 2016 [cited 2017 May 31];2(1). Available from: https://www.iproc.org/article/viewFile/iproc_v2i1e31/2

33. Samples C, Zhao N, Shaw RJ. Nursing and mHealth. Int J Nurs Sci[Internet]. 2014 [cited 2017 May 31];1(4):330-3. Available from: https://www.sciencedirect.com/science/article/pii/S2352013214000829

34. Catalan VM, Silveira DT, Neutzling AL, Martinato LHM, Borges GCM. The NAS System: Nursing Activities Score in mobile technology. Rev Esc Enferm USP[Internet]. 2011 [cited 2017 May 31]; 45(6):1419-26. Available from: http://www.scielo.br/pdf/ reeusp/v45n6/en_v45n6a20.pdf

35. Nielsen J. Heuristic evaluation. In: Nielsen J, Mack RL, (Eds.). Usability inspection methods: heuristic evaluation. New York: John Wiley \& Sons; 1994.

36. Marin HF, Peres HHC. O ensino de informática em saúde e o curriculum de enfermagem. J Health Inform[Internet]. 2015[cited 2017 May 31];7(4). Available from:http://www.jhi-sbis.saude.ws/ojs-jhi/index.php/jhi-sbis/article/view/449/248

37. Figueiredo AE. Laboratório de Enfermagem: estratégias criativas de simulações como procedimento pedagógico. Rev Enferm 
UFSM[Internet]. 2014[cited 2017 May 31];4(4):844-9 Available from: https://periodicos.ufsm.br/reufsm/article/view/11474/pdf

38. Juliani CMCM, Silva MC, Bueno GH. Avanços da Informática em Enfermagem no Brasil: revisão Integrativa. J Health Inform[Internet]. 2014[cited 2017 May 31]; 6(4):161-5. Available from: http://www.jhi-sbis.saude.ws/ojs-jhi/index.php/jhi-sbis/article/view/322/218

39. Silva ISA, Marques IR. Conhecimento e barreiras na utilização dos recursos da Tecnologia da Informação e Comunicação por docentes de Enfermagem. J Health Inform[Internet]. 2011[cited 2017 May 31];3(1):3-8.Available from: http://www.jhi-sbis.saude. ws/ojs-jhi/index.php/jhi-sbis/article/view/127/42

40. Arrais RF, Crotti PLR. Revisão: aplicativos para dispositivos móveis ("Apps") na automonitorização em pacientes diabéticos. J Health Inform[Internet]. 2015 [cited 2017 May 31];7(4):127-33.Available from: http://www.jhi-sbis.saude.ws/ojs-jhi/index.php/ jhi-sbis/article/view/359/245

41. Telesintese. GSMA defende marco regulatório para 'mobile health' deslanchar no Brasil [Internet]. 2013 [cited 2017 May 31]. Available from:http://www.telesintese.com.br/gsma-quermarco-regiulatorio-para-mobile-health-no-brasil. 